\title{
A estirpe de conselheiros do catolicismo popular sertanejo do nordeste brasileiro
}

The strain of advisers of popular Catholicism in the backwoodsof

northeasternBrazil

https://doi.org/10.29327/256659.12.2-12

\section{Resumo:}

Este artigo trata dessa "matriz geradora de uma estirpe de conselheiros do povo". O fenômeno religioso que se constituiu em torno dos conselheiros se deu basicamente na região do sertão nordestino, no semiárido, o que não exclui que seguidores tenham saido de outras sub-regiões. Movimentos dessa natureza dizem respeito à tradição e à cultura popular sertaneja, que têm raízes nas culturas africanas e indigena. Nas pequenas cidades do interior do Nordeste, ainda hoje deparamos com os conselheiros e as conselheiras que auxiliam as pessoas da comunidade, aconselhando-as em suas angústias, suavizando os seus sofrimentos. Essa estirpe cultural merece ser examinada mais de perto porque revela essa dimensão ainda pouco estudada do catolicismo popular brasileiro: a figura do conselheiro. Para estudar a estirpe de conselheiros, o ponto de partida foi recolher o material existente nas pesquisas bibliográficas e documentais.

Palavras-chave: Estirpe. Conselheiro. Nordeste.

\section{Abstract:}

This article deals with a "matrix that generates a strain of councilors of the people". The religious phenomenon that has taken place around the councilors occurs basically in the region of the Brazilian northeastern backwoods, in the semiarid region, which does not exclude that followers have left other sub-regions. Movements of this nature concern the tradition and popular culture from these backwoods, which are rooted in African and indigenous cultures. In small towns in the inner part of the northeast region, we still come across counselors who help people in the community, advising them in their anguish, softening their suffering. This cultural strain deserves to be examined more closely because it reveals this still-under-studied dimension of Brazilian popular Catholicism: the figure of the councilor. In order to study the strain of counselors, the starting point has been to collect the existing material in bibliographic and documentary research.

Keywords: Strain; Counselor; North East.

*Doutorando em Ciências da Religião pela PUC Minas (2019-2022). Mestre em Ciências da Religião pela PUC-Minas. Especialização em Docência no ensino superior: novas linguagens e novas abordagens pela PUC Minas. Licenciatura Plena em Filosofia pela PUC Minas. Professor de Educação Básica da Secretaria do Estado da Educação de Sergipe. Membro da SOTER.E-mail: jooevertoncruz@yahoo.com.br. 


\section{Introdução}

Neste artigo tentarei evidenciar a estirpe de conselheiros do catolicismo popular sertanejo do Nordeste brasileiro. São eles: o padre José Antônio Maria Ibiapina1 (1806-1883), beato Antônio Vicente Mendes Maciel22 (1830-1897), padre Cícero Romão Batista ${ }^{3}$ (1844-1934) e frei Damião de Bozzano4 (1897-1997) que inte-gram essa forma de catolicismo, na segunda metade do século XIX e primeira do século XX. Ao estudar esse tema como estudante da primeira turma de mestrado (2010) em Ciências da Religião do Programa de Pós-Graduação da PUC Minas, impressionou-me a complexidade dessa estirpe de conselheiros, aparentemente tão simples, sob a orientação do Prof. Dr. Pedro A. Ribeiro de Oliveira.

O fenômeno religioso é parte integrante de toda a história da humanidade, pois, a Fenomenologia da Religião vê na religiosidade um dos elementos da natureza humana. Por isso, a experiência religiosa implica em um sentimento de comunhão profunda com outras pessoas, com a natureza e com o sagrado. O sertanejo do Nordeste brasileiro ao longo dos anos apropriou-se dessa tradição de estirpe de conselheiros via o substrato religioso. A tradição religiosa dos nordestinos revive, porém diluída no tempo, é uma grandeza de variante oral, alicerçado na memória popular e revitalizada pela recordação itinerante, atraindo fatos e figuras. São as pessoas dos "velhos curas", do "padrim-padre", do "padre-mestre" e do missionário, celebrando, confessando, pregando, casando, aconselhando, dirimindo desavenças, emudecendo bacamarte e cravando cruzes em pontos elevados, sobretudo nas classes populares por meio dos antigos missionário, romeiros, cangaceiros, vaqueiros, poetas, cordelistas, parteiras, rezadeiras, leigos, beatas e beatos ${ }^{5}$, sendo padre Ibiapina "essa figura matricial" da estirpe de conselheiros na segunda metade do século XIX.

O Nordeste do Brasil abrange os Estados do Maranhão, Piauí, Ceará, Rio Grande do Norte, Paraíba, Pernambuco, Alagoas, Sergipe e Bahia. A região Nordeste tem a sua riqueza geográfica, dividida em quatro sub-regiões, bem distintas, com diversas condições climáticas e culturais. O litoral, com chuva constante; o sertão-semiárido, com escassas chuvas e intermináveis secas; o agreste e a zona da mata com chuvas abundantes. O fenômeno se deu basicamente na região do sertão nordestino, no semiárido, ao Norte do rio São Francisco.

O artigo está organizado em dois capítulos, dialogando com as leituras das pesquisas existentes e da bibliografia documental.

O primeiro capítulo abre com "as malhas diversificadas de um catolicismo, 
ou poder-se-ia mesmo falar em catolicismos no plural", na perspectiva de Faustino Teixeira (TEIXEIRA, 2009, p. 19-20). O segundo capítulo apresenta uma breve biografia de cada um dos conselheiros.

\title{
Conselheiros do catolicismo popular: sertanejo?
}

A tradição do catolicismo popular sertanejo do Nordeste brasileiro, onde surge "essa matriz geradora de uma estire de conselheiros do povo" foi uma questão lançada por Eduardo Diatahy B. de Menezes,

\begin{abstract}
Mas quem foi Ibiapina, essa matriz geradora de uma estirpe de conselheiros do povo (Antônio Vicente Mendes Maciel, Padre Cícero, Beato Lourenço, etc), instituindo nos sertões nordestinos da segunda metade do século XIX uma grande escuta dos anseios e aflições de larga massa de excluídos, e inaugurando uma forma de organização que a nossa civilização litorânea dominante teimará em não aceitar e até em hostilizar ou destruir sistematicamente quase todas as suas manifestações (MENEZES, 1996, p. 2).
\end{abstract}

A experiência religiosa de um conselheiro, especificamente, possa se assemelhar ou não com a experiência do aconselhamento do outro, configurando semelhanças e dessemelhanças entre eles. São todos nascidos em anos mais ou menos subsequentes. Uma nota a ser feita é que o conselheiro não é necessariamente um especialista da hierarquia da Igreja Católica. Duglas T. Monteiro retoma José Calasans para distinguir o conselheiro do beato pelo fato de seu "reconhecimento e aceitação como predicadores" (MONTEIRO, 1985, p. 69). Convém ainda observar que tanto padres quanto beatos ou beatas podem tornar-se conselheiros. Desse modo, Galvão diz que:

Antônio Conselheiro é apenas um entre os vários conselheiros de que há notícias na época: havia um por nome Francisco, em Itiúna, na Bahia, outro por nome Guedes, em Pernambuco, e outros mais. Assim eram designados no sertão os leigos andarilhos pregadores de sermões, chamados "conselhos" por não provirem de padres ordenados. (GALVÃO, 2001, p. 32).

A grande figura do padre conselheiro é, sem dúvida, o Pe. Cícero Romão Batista. Também o missionário frei Damião de Bozzano, um remanescente da disciplina tridentina, dava muita atenção à confissão e ao aconselhamento público em seus sermões, respondendo bilhetes que lhe mandavam ou the chegavam às mãos. 


\title{
O catolicismo popular: a dinâmica da produção religiosa
}

Para conhecer as diferentes formas de catolicismos existentes no Nordeste do Brasil, apelamos para a sociologia, porque exibe a dimensão humana e social de toda e qualquer religião. O catolicismo popular está presente no Brasil desde a chegada dos colonizadores portugueses, conquistando as terras e subjugando os povos indigenas. A expressão catolicismo popular é conceituada algumas vezes como "religião popular", "catolicismo rural", dentre outros, conforme Silva (2005, p. 20). Segundo o sociólogo Pedro A. Ribeiro de Oliveira (1985),

\begin{abstract}
A autoprodução religiosa popular não fica portanto separada da produção oficial, mas guarda com ela uma relação dialética: ela exprime as condições de existência das classes dominadas e subalternas, fazendo uso dos códigos religiosos oficiais. Podemos então definir o Catolicismo Popular como um conjunto de representações e práticas religiosas autoproduzidas pelas classes subalternas, usando o código do catolicismo oficial. Isso significa que o Catolicismo Popular incorpora elementos do catolicismo oficial os significantes - mas lhes dá uma significação própria, que pode inclusive opor-se à significação que lhes é oficialmente atribuída pelos especialistas. O resultado é que o mesmo código religioso é diferentemente interpretado pelas classes sociais de maneira que, sob uma unidade formal, escondem-se, de fato, diversas representações e práticas religiosas (OOLIVEIRA, 1985, p. 135).
\end{abstract}

O centro do catolicismo popular é a devoção ao santo e santa, do qual se espera proteção para superar as dificuldades e resolver os problemas desta vida, bem como obter a salvação eterna. As suas práticas religiosas são de âmbito familiar e em pequenos grupos e manifestam-se por atos concretos ligados ao cotidiano, como rezar para pedir chuva, visitar doentes e fazer leitura da Bíblia ${ }^{6}$. Esse catolicismo conta com os rituais oficiais (missa e sacramentos) e acrescenta novos sentidos para torná-los mais funcionais para sua vida (batismo-saúde, confissão-cura, sacramento-compadrio). Os rituais, além de situar contato com o sagrado, permitem recriar a consciência coletiva do povo. É um catolicismo conduzido pelos leigos e leigas. Não se pode concluir que seja um catolicismo independente do catolicismo romanizado, mas se trata de uma retradução do mesmo.

\section{Catolicismo popular sertanejo: a tradição camponesa de devoção}

É certo que o catolicismo popular sertanejo nos dias de hoje quase não existe mais, devido ao grande combate que ele tem aturado. Muito embora ainda restem tradições das velhas práticas, nas pequenas regiões onde há ausência de 
padres. A deficiência de padres no Brasil é caso que pode ser datado do período colonial. Os clérigos originários do "além-mar" eram em pequenina quantidade. As populações interioranas - nordestina com toda sua extensão ficaram sem sacerdotes. Ali se conservou um catolicismo popular sertanejo, com suas formas de crer e de agir especificamente, cultivada por leigos e leigas que se arvoravam nos assuntos religiosos, a fim de orientar o povo. Mais tarde, é verdade, com a Proclamação da República, as Ordens Religiosas estrangeiras passaram a enviar sacerdotes em maior quantidade para o Brasil, respeitado "pais das santas missões". Isto porque, esclarece Thomás Bruneau (1974, p. 29), e segue sucintamente: a) estar presentes, segundo um princípio organizacional, em todo território, por meio das missões, capelas, paróquias e dioceses; b) possuir, inclusive pela força, o monopólio dos fiéis, convertendo e/ou evangelizado a brancos, negros e índios; c) constituir e regulamentar a sociedade, visando à salvação, inclusive com o apoio do Estado, desde o batismo até a extrema-unção, mediante ensinamentos religiosos e morais; d) utilizar os grupos sociais e as estruturas, inclusive as do Estado, como instrumentos de influência.

Muitos dos sacerdotes estrangeiros nas missões procuraram implantar entre o povo práticas e crenças mais ligadas ao catolicismo romanizado, mas, o sertanejo dava mais ouvidos aos beatos, que aos sacerdotes ordenados, preferindo seus conselhos às missas formais e demais sacramentos. Esse foi o catolicismo difundido no sertão do Nordeste pelos missionários por meio das santas missões, sobretudo pelos capuchinhos franceses e italianos. Eduardo Hoornaert, com outra preocupação, esclarece de outra forma, a mesma coisa que:

O sertanejo nordestino vive imerso num mundo referencial bíblico e cristão, reconhece os símbolos, sabe interpretar as figuras. É herdeiro de uma longa e bonita tradição teológica, sendo ele mesmo teólogo. Teólogo sofrido, de mãos calejadas, mas teólogo. Embora não acostumado ao mundo das letras, produz versos, poesias e textos que não são de forma nenhuma simplórios, mas carregados daquela sabedoria sofrida típica do povo da terra, feita de desencanto mas também de uma esperança indestrutivel. Sertanejo-teólogo, cioso em descobrir o sentido mais profundo das coisas, concentrado em encontrar uma leitura teológica dos fatos que presencia. Não cartesiano no sentido de se operar uma rígida separação entre a racionalidade e a emotividade, entre os conceitos claros e as imagens, entre o experimentado e o sonhado. Mas um curioso das coisas de Deus, atrás do sentido último. Sua teologia é mística e escatológica, espera um tempo bom após tanto sofrimento. Com o dizia Câmara Cascudo: o sertanejo é teólogo "antes, durante e depois dos concílios ecumênicos e dos Santos Padres" 
(HOORNAERT, 1997, p. 63-64).

A devoção sertaneja nordestina corresponde a uma cultura de tradição baseada na oralidade. No catolicismo popular sertanejo existe uma hierarquia, o beato está abaixo do conselheiro. O beato tinha como função angariar esmolas para edificação de igrejas, capelas, cemitérios, e conduzia os cantos, puxava terços, dirigia as rezas. O beato podia ter uma progressão, quando ele "adquiria condições para, além disso, proferir prédicas, ou conselhos, passava a conselheiro" (GALVÃO, 2001, p. 33). Os papéis desses religiosos leigos são definidos por José Calasans Brandão da Silva,

\begin{abstract}
Admitimos, na igreja popular sertaneja, uma hierarquia, com beatos e conselheiros. Tivemos, como já foi dito, nossa atenção despertada para o assunto numa conversa com Honório Vilanova, em terras do Assaré. Disse-nos que conhecera, por volta de 1873, no Ceará, o beato Antônio, que iria encontrar, depois, na Bahia, como conselheiro. Explicou-nos que conselheiro era mais do que beato. Ao beato cabia a missão de tirar rezas, cantar ladainhas, pedir esmolas para obras da igreja. O conselheiro ia além, porque, melhor preparado sobre os temas religiosos, pregava, dava conselhos. Um conselheiro pode ter, debaixo de suas ordens, um ou vários beatos. Foi o caso de Antônio Conselheiro, ao qual estavam subordinados alguns beatos, como o beato Paulo, José Beatinho, Antônio Beatinho, além de outros que não nos foi possivel identificar (SILVA, 1986, p. 13).
\end{abstract}

Durante a pesquisa, deparamo-nos com várias pessoas que exercem a função de conselheiros na sua localidade, pois, são reconhecidas por algumas qualidades que os caracterizam: virtudes pessoais, força da palavra, capacidade de ouvir, intimidade com os santos. Em Canudos (BA), Antônio Conselheiro (1830-1897) usava a Missão Abreviada e as Horas Marianas diariamente. Era uma espécie de pequeno Manual dedicado a Maria, Mãe de Jesus Cristo. Em decorrência da renovação estabelecida pelo episcopado através do Concílio vaticano I, o catolicismo popular sertanejo baseado na figura do beato é interpretado como negação à prática do catolicismo romanizado e não como uma forma popular de fazer catolicismo. Esse preconceito por parte da cultura oficial ocorre em não pretender compreender os diferentes elementos significativos que constituem esse catolicismo, estabelecendo uma dicotomia cultural que se exprime na existência de uma cultura oficial dominante e outra meramente popular e muitas vezes considerada como algo periférico e supersticioso. 


\section{Catolicismo romanizado: influência na organização da vida eclesiástica}

O catolicismo romanizado pode ser datado a partir de 1858. A inquietação do catolicismo romanizado era afugentar os fiéis do catolicismo popular e orientá-los para a prática do catolicismo romano, com ênfase nos sacramentos. Sobre a "romanização" do catolicismo brasileiro, Pedro R. de Oliveira diz que:

Um documento confidencial de D. Macedo Costa, intitulado "Pontos de reforma na Igreja do Brasil", apresenta as grandes linhas de reforma por ele propostas ao conjunto do episcopado brasileiro. Redigido em 1890, ele tem cerca de 20 páginas e é dividido em 9 capítulos. Analisando suas propostas, teremos um panorama do projeto de reformas do líder do episcopado brasileiro no início do período republicano (OLIVEIRA, 1985, p. 279-280).

No catolicismo romanizado os sacramentos assumem caráter obrigatório e um dos pontos levantados é, pois, a sua uniformidade de ação do episcopado brasileiro, como um único corpo, reforçando a sua autoridade diante do clero e hierarquia. O objetivo do catolicismo romanizado é a reforma do aparelho eclesiástico, sob outros aspectos, a regeneração religiosa do povo. A evangelização da sociedade brasileira foi marcada por duas tendências: a "pastoral da convivência" e a "pastoral da visita", assim destaca E. Hoornaert. (HOORNAERT, 2008, p. 125-133). Mesmo escassa, essa convivência servia para garantir o laço de pertencimento do catolicismo popular ao catolicismo oficial por meio de um consentimento religioso que fazia com que os diferentes grupos sociais que viviam espalhados pelo sertão admitissem como pertencentes à única e mesma Igreja da hierarquia eclesiástica. Há uma distância que marca a religiosidade e a vivência concreta do sertanejo; sendo que essa vivência religiosa pouco auxilia para a libertação dos seus problemas, desencadeando na mistificação, alienação e até opressão. A fome, a seca, a miséria e a pobreza seriam então transfiguradas como decorrência de leis divinas e, portanto, imutáveis. Bourdieu evidencia o caráter dominante da religião, quando diz que

Neste ponto, Weber está de acordo com Marx ao afirmar que a religião cumpre uma função de conservação da ordem social contribuindo, nos termos de sua própria linguagem, para a "legitimação" do poder dos "dominantes" e para a "domesticação dos dominados". E ademais, Weber nos fornece os meios de escapar à alternativa simplista de que são produto suas análises mais duvidosas, ou seja, à oposição entre a ilusão da autonomia absoluta do discurso mítico ou religioso e a teoria reducionista que torna esse discurso o reflexo direto das estruturas sociais. Procura esclarecer 
ao máximo o elemento comum ausente no discurso das duas posições opostas e complementares: o trabalho religioso realizado pelos produtores e porta-vozes especializados, investidos do poder, institucional ou não, de responder por meio de um tipo determinado de prática ou discurso a uma categoria particular de necessidades próprias a certos grupos sociais. (BOURDIEU, 1974, p. 32-33).

O contexto sociológico onde acontece o fenômeno religioso em torno dos notáveis conselheiros é o sertão nordestino. Com a estirpe de notáveis conselheiros dentro das expressões religiosas sertanejas que vivia sob os olhares e o controle da hierarquia eclesiástica, que tinha como critério de valor a observância da "lei" e da "obrigação", é o que veremos a seguir.

\section{Padre Ibiapina, Beato Antônio Conselheiro, Padre Cícero e Frei Damião: a estirpe de conselheiros}

A estirpe de conselheiros do catolicismo popular sertanejo é uma herança cultural que se propagou por muito tempo, tendo maior valor os padres missionários que davam mais conselhos ${ }^{7}$. Os bons confessores eram, portanto, todos aqueles que seguravam aos seus pés o devoto, por mais tempo, dando conselhos e mais conselhos. A distância que nos afasta dos notáveis conselheiros da memória dos sertões nos permite discernir com exatidão a importância das suas vidas e de suas obras materiais e espirituais para a população do Nordeste brasileiro. Vejamos cada um deles.

\section{Padre Ibiapina}

José Antônio de Maria Ibiapina8 nasceu em 5 de agosto 1806, na fazenda Morro da Jaibara, em Sobral (CE). Era conhecido como Pereirinha. Filho de Francisco Miguel Pereira e Tereza Maria de Jesus. Seu pai era um agricultor em Sobral e tabelião no Icó. Sua mãe falecera vitimada por abortamento. Em 1824, seu pai e o irmão Alexandre participaram da revolução denominada Confederação do Equador. O pai foi fuzilado em praça pública em Fortaleza em 7 de maio de 1825. Quanto a seu irmão, foi preso e levado para Fernando de Noronha, onde faleceu. Os bens da família foram confiscados e José Antônio Ibiapina assume o comando da família. O nome "Ibiapina" foi uma homenagem do pai ao vilarejo que o recebeu nos primeiros anos de seu casamento, por isso decidiu colocar o nome do lugar em um dos filhos, daí que Ibiapina é o terceiro filho do casal e o primeiro a portar esse sobrenome. Ibiapina passa sua infância na cidade de Icó, 
para onde migrou a família, já que o pai foi nomeado tabelião, aí morando até 1819, quando foi transferido para a cidade do Crato (CE), residindo até meados de 1823. Em 1820, Ibiapina foi para a cidade de Jardim (CE), onde frequenta a aula de latim com o mestre Joaquim Teotônio Sobreira de Melo. Em 1823, Ibiapina, com 17 anos, foi com a família para Fortaleza, tendo seguido logo depois para o Seminário de Olinda, com o desejo de ser padre. Com a perda do pai em 1825, teve que voltar para o Ceará assumindo a direção da família e, com isso, interrompe seus estudos. No dia 3 de fevereiro de 1828, foi matriculado, pela segunda vez, no Seminário Episcopal de Olinda. No dia 11 de agosto de 1827 foi criado o curso de Ciências Jurídicas e Sociais em Pernambuco, e instalado em 15 de maio de 1828 no Mosteiro de São Bento, na cidade de Olinda. Aprovado nos exames preparatórios, Ibiapina foi matriculado com mais de quarenta companheiros. As aulas tiveram início em 2 de junho e a incompatibilidade de horários levou Ibiapina a fazer uma outra opção pelos estudos jurídicos, passando a residir no Mosteiro de São Bento.

Ibiapina foi um homem público. Após concluir o curso jurídico, seu nome foi remetido ao Ministério para fins de nomeação de professor de Direito Natural, que foi aceito por unanimidade no dia 10 de outubro de 1832. Com a chegada das férias escolares, resolveu viajar ao Ceará para rever familiares e amigos; acabou conhecendo Carolina Clarence de Alencar Araripe (1867), por quem se apaixonou, marcando o casamento para as férias escolares seguintes. Encerrando o ano letivo, retornou ao Ceará para realizar o casamento e acertar a nova residência no Rio de Janeiro como deputado geral. Mas, ao chegar a Fortaleza, recebeu a notícia de que a noiva havia fugido e se casado com o primo Antônio Ferreira Lima Sucupira. Após o encerramento da sessão legislativa de 1834, Ibiapina viaja para o Ceará para assumir as funções de Juiz de Direito e Chefe de Polícia de Quixeramobim (CE), trabalhando por pouco tempo. Ibiapina não aceitou a Presidência da Província de Pernambuco (governador), tampouco a pasta do Ministério da Justiça.

A partir de 1838, Ibiapina passou a residir no Recife (PE), mas foi convidado para advogar na Vila Real do Brejo de Areia (PB). Por volta de 1840, fixa morada em Recife, onde instalou escritório de advocacia no pátio do Carmo, por dez anos, recebendo o título de "defensor dos pobres", por ser um dos mais notáveis advogados do Recife (PE). Sua vida em reclusão foi por volta dos 1850 a 1853. Sendo que, em 1850, Ibiapina fechou o escritório e renunciou à carreira de advogado, passando a residir numa casa de tijolos no sítio Caxangá, no Recife, 
recluso na solidão, rezando, estudando teologia e filosofia. Para uns, monge; para outros, louco. Seja como for, cuidava do jardim e do pomar, em companhia da irmã caçula Ana, e mantinha contato com o bispo Dom frei João Marques da Purificação Perdigão. Dom João foi quem o ordenou, recebendo a tonsura clerical aos 11 de junho de 1853. No dia seguinte aos 12 de junho do mesmo ano recebeu as duas primeiras ordens menores de hostiário e leitor. E, aos 18 de junho de 1853, recebeu as ordens de exorcista e acólito. No dia 19 de junho lhe foi conferido o subdiaconato. No dia 26 de junho, o diaconato. No dia 3 de julho ordenou-se sacerdote aos 47 anos de idade. No dia 26 de julho de 1853, celebrou a primeira missa na Igreja Madre de Deus, no Recife. Sobre as obras e peregrinações do Pe. Ibiapina, Diana Rodrigues Lopes diz que

Padre Ibiapina, no seu incansável trabalho missionário, percorreu mais de $\mathbf{6 0 1 . 7 5 8}$ quilômetros pelas estradas do Piauí, Ceará, Rio Grande do Norte, Paraíba e Pernambuco, com sua batina de brim pardo ou branco, a pé, a cavalo, ao sol, a chuva, enfrentando doenças e animais ferozes e poderosos fazendeiros. Realizou missões, organizou o povo, conciliou velhas intrigas, levantou e restaurou capelas e igrejas, fundou hospitais, construiu açudes, cacimbas, poços, barragens em mutirão, com a comunidade pobre e sofrida do sertão, sem nenhum apoio e ajuda oficial. Construiu 22 Casas de Caridade, para atender a carentes e órfãs, que eram entregues às irmãs de caridade ou chamadas de beatas. Nas Casas de Caridade as abrigadas aprendiam a ler, escrever e contar, educação religiosa e moral (LOPES, 2004, p. 37, negritos da autora).

Padre Ibiapina, no decorrer dos trinta anos de ação missionária, influenciou a intensificação do preparo de beatos-leigos, no sertão, levando ao povo sofrido nordestino palavras de conselho, atuando na conversão e no acolhimento com suas 22 Casas de Caridade, aos órfãos vítimas do cólera. Como conselheiro do povo, foi, à maneira dos antigos santos e missionários, suscitando inevitáveis ambiguidades, incompreensões; causando conflitos e tensões de renovação dentro da hierarquia eclesiástica face ao movimento dos beatos que surgiu no século XIX, com ele mesmo. Em Serra Talhada (PE), o missionário Ibiapina promoveu a paz entre famílias em litígio, segundo Francisco Sadoc de Araújo:

Ordenou que cavasse um buraco em frente da matriz, para ali serem enterradas todas as armas brancas e de fogo, que estivessem em poder de particulares. Com esse gesto simbólico, pretendia levar inimigos políticos à reconciliação e famílias desavindas à convivência amistosa e à paz doméstica. Com menos armas disponíveis, também o cangaceirismo, que se alastrava pelo sertão, haveria de diminuir (ARAÚJO, 1996, p. 309). 
Foi protetor da natureza, pacificador e introduziu no sertão a prática do mutirão, levando ao cooperativismo. Padre-Mestre Ibiapina morreu no dia 19 de fevereiro de 1883, em sua residência ao lado da Casa de Caridade de Santa Fé (PB), numa segunda-feira da segunda semana da quaresma, aos 77 anos de idade. A fama de santidade, firmada no exercício heróico das virtudes e guardada na memória popular, fundamentou a abertura de sua causa de canonização, ora em tramitação no Vaticano.

\title{
Beato Antônio Conselheiro
}

Antônio Vicente Mendes Maciel$^{9}$ (1830-1897), o futuro Antônio Conselheiro, que era filho de Vicente Mendes Maciel e Maria Joaquina do Nascimento - de alcunha Maria Chana -, nasceu na Vila do Campo Maior de Quixeramobim (CE). Com o falecimento de sua mãe, seu pai teve de casar-se pela segunda vez. O menino Antônio Vicente era apegado à sua mãe. As divergências entre o menino e sua madrasta começam a tomar proporções assustadoras, a ponto de esta induzir o marido a internar o menino num seminário. O pai concordou com a ideia, mas, o filho se posicionou de forma antípoda, preferindo permanecer sob o desprezo, o autoritarismo, a arrogância e os maus-tratos da madrasta. Daí por diante o clima familiar era da mais completa hostilidade ao garoto. Em 1857, Antônio Maciel casa-se com Brasilina Laurentina de Lima, na matriz de Quixeramobim. Foi caixeiro viajante, auxiliar de cartório e professor. Eduardo Hoornaert afirma que:

\begin{abstract}
Seu companheiro de infância, o jornalista João Brígido, conta em 1917 que Antônio Vicente teve uma aprimorada formação em letras primárias e latim, ainda em Quixeramobim, o que lhe deu condições de exercer mais tarde as funções de escrivão do juiz de paz em Ipu. Dos tempos em que estudava com seu mestre de latim e gramática em Quixeramobim, guardou uma boa capacidade de escrever e traduzir frases biblicas, conforme se pode averiguar nos cadernos guardados. Toda essa ambientação, que não era incomum no sertão do século XIX, fez dele um "homem de letras", e mais tarde um escritor (HOORNAERT, 1997, p. 114).
\end{abstract}

Em 1860, Antônio muda-se para a cidade de Campo Grande; nasce seu segundo filho. Abandonado por sua mulher e perseguido pelos credores, deixou o Ceará e tornou-se um beato. O enfraquecimento, no século XIX, do aparelho eclesiástico beneficiou o desenvolvimento do catolicismo popular sertanejo, sustentado pelos beatos, rezadores, monges, capelães. Sem a presença do clero na 
administração dos sacramentos, abriu espaço para a atuação do beato Antônio Conselheiro. O movimento desenvolvido pelo beato foi constituído em acordo com os hábitos de uma cultura popular sertaneja, aliado a uma onda mística e religiosa. Como beato, ele era um penitente sertanejo de moral rígida, hábitos familiares, com um discurso religioso e uma prática social contestadora. Na condição de beato itinerante reúne gente para a construção de obras religiosas como edificação ou restauração de capelas, cemitérios etc. O conteúdo de suas pregações se estabelece.

Numa ordem divina que admite desigualdades e que reserva a cada um, conforme sua posição, determinados direitos e deveres. Quanto aos deserdados - aos pobres - há para eles o consolo de que, pelo caminho das privações e sofrimentos, o céu pode ser alcançado e, ao mesmo tempo, a recomendação de conformismo com a sorte, porção que Deus lhes reservou piedade filial e devotamento dos pais para com os filhos, ao lado de um rígido puritanismo, são os traços distintivos, no que se refere às recomendações sobre o trato entre gerações e entre os sexos. A lei é necessária e, com ela, os juízes e outros poderes deste mundo. (MONTEIRO, 1974, p. 65-66).

Ao seu modo, entregou-se à vida peregrina, desempenhando o papel de um exímio conselheiro dos nordestinos. Antônio Conselheiro é um líder que cumpre o papel religioso de, em nome de uma ordem divina, aperfeiçoar o comportamento dos sertanejos com suas ideias de castigo, pecado, promessa de redenção e de reconciliação. O beato lutava para preservar as virtudes tradicionais, ameaçadas pela modernidade republicana e, assim fazendo, percorreu o sertão do Ceará, de Pernambuco e de Sergipe; entrou na Bahia, tomou conta de uma fazenda abandonada. José Calasans, diz que

Além das obras das igrejas, o Conselheiro pregava aos seus fiéis, o que fazia com freqüência. Eram os "dias de conselho". Conhecedor da Bíblia, ledor da Missão Abreviada, livro de larga divulgação no interior do Brasil, o Conselheiro falava sobre os mandamentos, condenava os pecados, aconselhava para o bem, citando, não raro, frases latinas. (SILVA, 1997, p. 59, negitos do autor).

Antônio Conselheiro ganha nome nacional e internacional, pois foi personagem central do romance de Mario Vargas Llosa, La guerra del fin del mundo (1981), baseado na história do beato que virou "Conselheiro" e fundador de um movimento religioso milenarista no Brasil rural, nos fins do século XIX, Canudos (BA), pois para Ele a República é o anticristo. Monteiro diz que 
[...] é evidente que a república permanece sobre um princípio falso e dele não se pode tirar consequência legítima: sustentar o contrário seria absurdo, espantoso e singularíssimo; porque, ainda que ela trouxesse o bem para o país, por si é má, porque vai de encontro à vontade de Deus, com manifesta ofensa de sua divina lei (MONTEIRO, 1977, p. 59).

Os grandes latifundiários e poderosos ficam contra ele e veem nele o perigo à ordem estabelecida. A missão de Antônio no Arraial de Canudos alia-se ao trabalho desenvolvido por padre Ibiapina nas terras dos sertões. O beato tinha a mesma aptidão e imagem performática de missionários dos antigos capuchinhos que andavam pregando as santas missões pelas cidades e lugarejos do Nordeste; vivia como um deles: a barba grande, o hábito desbotado, sempre de sandálias; a coragem diária, o costume das missões sem nenhum conforto. Galvão diz que:

Havia dois oficios diários, à madrugada e à noitinha ou fim da tarde, e periodicamente os conselhos com data marcada, para os quais acorria gente até de longe, ansiosa por ouvir a palavra do Peregrino. Canudos assim tornou-se um centro de romaria, atraindo crentes que ali chegavam para pedir audiência e fazer doações (GALVÃO, 2001, p. 45).

O cenário da época do beato era de um catolicismo popular sertanejo herdado da cultura portuguesa. Pode-se ligar Antônio Conselheiro e padre Cícero aos protestos sociais e ao distanciamento da hierarquia eclesiástica. Suas pregações revelam ser um homem letrado e inteligente, inspiração das Missões Abreviadas e das Horas Marianas - teologia corrente na época - tratam da criação, da elevação, do castigo, do pecado, da promessa e de reconciliação com Deus.

\section{Padre Cícero}

Cícero Romão Batista ${ }^{10}$ nasceu na cidade do Crato (CE), na Rua Grande, hoje Rua Miguel Limaverde, em 24 de março de 1844. Seus país, Joaquim Romão Batista, um pequeno comerciante de tecidos e ferragens. Sua mãe, Joaquina Vicência Romana, conhecida como Dona Quinô, era dona de casa. O núcleo familiar incluía duas irmãs. Cícero foi o primogênito e único filho homem desta família de condição média (casa própria de tijolo, quatro pedaços de terra e uma mercearia). Cícero Romão Batista foi ordenado subdiácono no dia 20 de novembro e no dia 27 do mesmo mês foi ordenado diácono, sagrando-se sacerdote no dia 30 de novembro de 1870 por Dom Luís Antônio dos Santos, primeiro bispo do Ceará, (formado pelos lazaristas dentro do espírito tridentino). Em abril de 1872, assu- 
miu a função de capelão em Juazeiro do Norte (CE), onde chegara em 1871. Naquele tempo, o arraial de Juazeiro possuía cinco casas de telha e 50 de palha. Diante das necessidades pastorais que encontra em Juazeiro, decide ali permanecer com seus familiares.

O zelo pastoral de Pe. Cícero o leva a uma ação que visava orientar, organizar e moralizar com energia e rigor não apenas a vida religiosa, mas também social do lugar. Abraça a causa e começa a se impor como pregador, conselheiro e moralizador dos costumes da época, fundando em Juazeiro do Norte as Conferências Vicentinas e o Apostolado da Oração. Dedicando-se a corrigir os vícios do povo e também os abusos morais, chegando a proibir as danças, conseguiu que os homens parassem de bater nas mulheres e obrigou as prostitutas a confessar seus pecados. Com o tempo, Juazeiro passou a ser um modelo de ordem social e de virtude. Durante muito tempo padre Cícero permaneceu na pobreza. Não quis receber nada pelos sacramentos que administrava. Adquiriu fama de um sacerdote dedicado inteiramente ao povo do sertão, sempre disponível, atento, um excelente conselheiro do povo, aceitando trabalhar na capelinha mais empobrecida da diocese.

Antes de acontecer o milagre da hóstia consagrada que teria vertido sangue na boca da beata Maria de Araújo, padre Cícero já tinha fama de santo, de profeta e de milagreiro pelo povo do Nordeste. No período da "Grande Seca" de 1877-1878-1879, marcou o Nordeste e padre Cícero fez a promessa de levantar uma grande igreja, em honra do Sagrado Coração, no alto da serra do Catolé, na seguida seca de 1888. Com as chuvas as obras tiveram início, cumprindo, assim, a promessa recebida do retorno das chuvas nos sertões. Após estar estabelecido há dezessete anos em Juazeiro, padre Cícero, no dia $1^{\circ}$ de março de 1889 (foi também um ano de seca), depois de uma longa vigília noturna de oração, ao dar a comunhão para Maria de Araújo, presencia o fenômeno extraordinário do sangramento da hóstia, fato que se repete em diversas ocasiões. O milagre protagonizado pela beata Maria de Araújo, Lima sugere:

[...] quatro hipóteses para o fenômeno da "comunhão ensanguentada". A primeira é apoiada pelo "Padrim" e pelos médicos que fizeram o primeiro exame concluindo como evento de natureza miraculosa. A segunda é defendida pela igreja oficial que aponta o acontecido como fruto de superstição, fanatismo e abuso à "Santa Eucaristia". A terceira foi apresentada pelo Pe. Antônio Gomes de Araújo, e classifica o fato como um embuste patrocinado pelo Prof. José Marrocos em conivência com a beata; e finalmente le- 
vantada pelo Dr. Júlio César da Fonseca, qualificando o caso como fruto da influência do psiquismo sobre o organismo e, posteriormente, pela parapsicologia como caso de "aporte" (LIMA, 2008, p. 138).

Depois disso a sua atividade pastoral concentra-se no aconselhamento daqueles que o procuravam. Seus conselhos transpõem os limites de Juazeiro e atraem pessoas de todo Nordeste do Brasil. Sua palavra e ensinamentos penetram tanto nas casas senhoriais quanto nos casebres. Empenha-se para capacitar os sertanejos. Sua permanente busca pela readmissão no uso das sagradas ordens o leva, em 1898, a Roma, onde é autorizado a celebrar e é absolvido das sanções eclesiásticas. Seu bispo ordinário, dom Joaquim José Vieira, mantém a proibição de celebrar a missa. Nunes tem a seguinte observação:

Padre Cícero, impedido de exercer uma ação pastoral meramente sacramentaria, uma vez que estava suspenso do uso das suas ordens sacras, teve que realizar um trabalho que identificou com a ação de Ibiapina, realizando uma ação de conselheiro e padrinho lá onde se estrangulavam os angustiantes problemas da população. Há necessidade de solucionar os conflitos, de apaziguar os ânimos, de acolher tantos retirantes, de colocar jovens e adultos no campo do trabalho. Tudo isto é problema do quotidiano e as soluções devem começar aqui e não apenas na eternidade ditosa. E a estratégia de fazer de Juazeiro um lugar de oração e trabalho, fez de Juazeiro um lugar sagrado, onde se manifesta o poder de Deus não apenas nos fatos miraculosos, então, proibidos e censurados. Mas através de uma ação de aconselhamento que vê no trabalho a possibilidade de encaminhamento de muitas e muitas pessoas para uma vida mais decente, base futura de uma realidade mais abrangente. A palavra do Padre Cícero era a palavra da misericórdia de Deus: "quem matou não mate mais, quem roubou não roube mais, quem pecou não pegue mais" (NUVENS, 1994, p. 29-30).

Padre Cícero Romão Batista continua sua atuação, porém como conselheiro junto aos romeiros, em sua residência. Dentre seus inúmeros conselhos, destacamos alguns que fazem eco com a atualidade:

Não derrube o mato, nem mesmo um só pé de pau. Não toque fogo no roçado nem na caatinga. Não cace mais e deixe os bichos viverem. Plante cada dia pelo menos um pé de algaroba, de caju, de sabiá, ou outra árvore qualquer, até que o sertão seja uma mata só. Não plante serra acima, nem faça roçado em ladeira; deixe o mato protegendo a terra para que a água não arraste e não se perca sua riqueza (BARRETO, 2003, p. 44). 
Seus conselhos não perderam a validade com a distância no tempo, pois, o padre Cícero já aconselhava o povo no sentido de se preservar o meio ambiente para a sobrevivência de todos. Em suas cartas ele aconselha os fiéis: "não vá morar em terra de senhor de engenho. Não venda suas terras. Não queiram morar em terra alheia. Compre sua terra." (BARRETO, 2003, p.43). Lira Neto diz que "a exemplo dos pajés das antigas nações cariris, cujo sangue lhe corria nas veias misturado aos dos ancestrais portugueses, Cícero passara a acumular as funções de conselheiro, benzedor e curandeiro" (NETO, 2009, p.281). O padrinho, como é chamado pelos devotos, se insere dentro do contexto do compadrio, ligado às tradições populares, como observa Della Cava:

Juazeiro era, de fato, uma "cidade santa" presidida por um santo Patriarca, que era padrinho dos doentes, dos desabrigados, dos oprimidos, dos que tinham fome, dos criminosos e pecadores. Tachados de fanáticos pela sociedade culta do litoral, tais romeiros, pelo contrário, consideravam-se apenas afilhados do Padre Cícero (DELLA CAVA, 1985, p. 141).

O apadrinhamento ainda permanece como uma das principais instituições da estrutura social nordestina, de acordo com Luitgarde Oliveira, pois:

Quando alguém usa a expressão "meu padrinho", é porque identifica nesta pessoa a capacidade muito pronunciada de se responsabilizar por seus afilhados. [...] Quando alguém se dirige a outro com a expressão "meu padrinho", está-lhe rendendo ao mesmo tempo gratidão, oferecendo-lhe fidelidade, tudo isso com o significado de um título que é também de orientador, aquele que merece respeito, enfim, é um símbolo de prestação de obediência, é a escolha espontânea de alguém que merece, por sua conduta, a confiança de dirigir e aconselhar suas próprias opções de vida (BARROS, 1988, p. 173).

A relação do padre Cícero com a população do sertão não se constitui pelo mandonismo e sujeição, como era uma prática dos coronéis diante dos seus agregados. Padre Cícero ao ser nomeado de padrinho pelos romeiros é expressão do prestígio de sua atitude acolhedora e protetora dos necessitados. Faleceu na manhã de 20 de julho de 1934, com 90 anos de idade, depois de ter recebido os últimos sacramentos. Foi um acontecimento de grande comoção popular no Nordeste brasileiro. O Papa Francisco, na Audiência de 5 de setembro de 2014, assinou o documento de "reconciliação histórica da Igreja com o padre Cícero". A espiritualidade dos romeiros de padre Cícero atrai, a cada ano, aproximadamente dois milhões a Juazeiro do Norte (CE). 


\section{Frei Damião}

Nasceu no dia 5 de novembro de 1898, num vilarejo denominado Bozzano, que pertence à cidade de Massarosa, no Norte da Itália. Batizado como Pio Giannotti, mais tarde viria a ser conhecido como Frei Damião de Bozzano ${ }^{11}$. Era filho do casal de camponeses Félix e Maria Giannotti. Durante sua infância, Pio Giannotti costumava ficar em silêncio, rezando e olhando a natureza. O menino tinha o costume de conduzir sempre o crucifixo. De vez em quando ele sumia. Depois de horas, os pais iam encontrá-lo, sempre sozinho e reflexivo, no sótão da casa onde moravam. Pio Giannotti começou a estudar religião aos 12 anos, na Escola Seráfica de Camigliano. Sua vocação começava a se manifestar e, quando completou 16 anos, ingressou na Ordem dos Capuchinhos, em maio de 1914. Recebeu o hábito religioso no Convento de Vila Basílica.

Era uma época conturbada na Europa, com a eclosão da I Grande Guerra Mundial. Exatamente por conta disso, aos 19 anos ele foi convocado para servir o Exército italiano, tendo que abandonar os estudos religiosos. Atuou como soldado por mais de três anos, permanecendo alojado em Zara, zona disputada pela antiga Iugoslávia. Mostrou-se sempre um soldado sem habilidade. Portanto, depois de concluído o Serviço Militar, abandonou a farda e retornou outra vez para os estudos religiosos. Estudou na Universidade Gregoriana de Roma de 1921 a 1925. Diplomou-se em filosofia, direito canônico e teologia dogmática. Ordenouse sacerdote em 5 de agosto de 1923, aos 25 anos. Em 1925, assumiu o cargo de vice-mestre de noviços do Convento de Vila Basílica. Três anos mais tarde foi para o Convento de Massa, atuando como diretor e também como professor de jovens religiosos.

Em 1931, com 33 anos, o missionário capuchinho Frei Damião de Bozzano deixou a Itália e, após breve estadia no estado do Rio de Janeiro, rumou para o Convento da Penha, em Recife, com outros dois missionários capuchinhos. Frei Damião como missionário capuchinho percorreu todos os estados do Nordeste. Era um missionário perambulante. A sua popularidade surge pelo seu contato permanente com o povo nas pequenas cidades do interior, e também pela sua virtude pessoal. Os biógrafos constatam que há quase unanimidade de que Frei Damião é um santo para os devotos. O frade se adaptou à mentalidade rural, às práticas religiosas e à linguagem bucólica do povo nordestino.

Em todo o Nordeste, por onde passava, Frei Damião conquistava as massas. Seu carisma junto à população foi largamente usado politicamente. O frade, 
com isso, tornou-se uma figura polêmica dentro da igreja devido às acusações de permitir-se manipular por políticos nordestinos. A partir daí passou a receber críticas da hierarquia eclesiástica devido aos novos movimentos que interpelavam uma renovação pastoral para subsidiar a demanda dos movimentos dos trabalhadores urbanos e rurais. Frei Damião não acompanhou essas renovações pastorais, mesmo depois do Concílio Vaticano II, que solicitava uma catequese renovada, inclusive para as dioceses do Nordeste, em especial a de Recife, que buscou colaborar com a agenda dos movimentos sociais através do arcebispo Dom Hélder Câmara. O frade capuchinho prosseguia com as mesmas pregações conservadoras que naturalizavam as desigualdades sociais e, permanecendo assim, não tomou partido em favor dos movimentos camponeses do Nordeste.

As Ligas Camponesas de Pesqueira, em Pernambuco, revelaram um Frei Damião avesso às organizações de trabalhadores rurais. A sua indiferença com relação às Ligas tinha como justificativa que elas não eram "democráticas", mas sim um movimento de camponeses desordeiros e comunistas. Frei Damião perde a noção do mundo real e mantém-se em uma tradição religiosa conformista. Como exemplo disso, citamos excertos de uma carta enviada ao frei pelo Advogado da Liga Camponesa12:

[...] soubemos para surpresa nossa, que V. Revma. fez propaganda contra a 'Liga Camponesa', ou seja, a Associação dos Agricultores de Pesqueira [...]

E fomos informados de que V. Revma. subiu nestes dias semiúmidos de primavera de primavera a serra Urubá, transpondo caminhos acidentados para fazer sermões, embora no mesmo lugar estivéssemos falando aos agricultores, cujos caminhos cortam os latifúndios por imprudência de gente que sonhou como homens livres [...] Essa Serra, outrora pertencia aos índios, mas estes a venderam em pedaços a troco de cachaça. Habitam hoje a Serra caboclos trabalhadores que discordam dos erros dos seus antepassados, caboclos que não dispõem de terras para trabalhar porque elas foram invadidas pelos bois. Hoje, a Serra mantém uma escravidão, porém diferente da outra porque é a submissão da terra pelo boi, que vive mais bem tratado do que seres humanos que habitam aquela região conquistada pela astúcia do homem branco. [...] Foi ali que estivestes, Frei Damião, também, onde pregastes a palavra do Mestre. Mas, proferistes uma palavra diferente porque combatestes uma organização de homens que desejam melhor salário, sindicalização [...] Fazemos generoso apelo a V. Revma. para que ajude a colocar mais uma pedra sobre as pedras da obra social existente na cidade de Pesqueira, de vez que a Igreja não pode ficar ausente dessa batalha de redenção do homem da foice, do machado e da enxada. O convite está lançado e, 
como nunca será tarde demais para acertar-se com o caminho da verdade, esperam os camponeses sem terra que a V. Revma. empreste sua valorosa colaboração, pregando a REFORMA AGRÁRIA por essa imensa região do Nordeste (PEREIRA, 1969).

O posicionamento do advogado Costa Pereira evidencia que Frei Damião nas suas pregações aconselhava os trabalhadores a não participarem das Ligas Camponesas de Pesqueira $(\mathrm{PE})$, que reivindicavam por melhores condições de salários. Os sermões do capuchinho contrários às Ligas impulsionaram também os fazendeiros de Pesqueira contra a organização dos camponeses. O frade se colocou entre os membros da Igreja que viam nas transformações a ameaça à tradição católica. Contradizer essa ordem era o mesmo que se insurgir contra Deus. Daí o entendimento de que o capuchinho ratificou a fé no sobre-humano, no eterno e não no transitório da história. Em contrapartida, nas eleições presidenciais de 1989, o então candidato Fernando Collor de Mello fez comícios ao lado de frei Damião na cidade de Juazeiro do Norte (CE) e distribuiu folhinhas eleitorais com a imagem do frade. No dia 31 de maio de 1997, aos 99 anos, morre frei Damião de Bozzano. Seu corpo foi embalsamado, velado durante três dias na Basílica da Penha, no Recife. O capuchinho está sepultado na Capela de Nossa Senhora das Graças, no Convento de São Félix de Cantalice, construída especialmente para ser seu mausoléu, e hoje é ponto de visitação de romeiros. Eis aí a razão pela qual, no dia 31 de janeiro de 2003, a Ordem dos Frades Menores Capuchinhos, deram entrada no Vaticano, com o processo de Beatificação e de Canonização do Servo de Deus frei Damião de Bozzano.

\section{Considerações finais}

Ao encerrar este artigo, convém apontas algumas considerações a modo de conclusão. Em primeiro lugar, devido a escassez de pesquisas confiáveis, tornase difícil uma teoria da função do conselheiro no catolicismo popular sertanejo do Nordeste brasileiro. Dessa forma, valorizamos algumas obras que substanciam nossa pesquisa por meio de livros publicados por sociólogos, historiadores e biógrafos de cada um dos conselheiros. Fica evidenciado que a figura do conselheiro ou da conselheira parece ser típica do catolicismo sertanejo do Nordeste. Nas pequenas e médias cidades do interior, nos dias de hoje, deparamos com a presença de pequenos conselheiros e conselheiras que auxiliam as pessoas da comunidade. Porque os conselhos estão colados na memória dos sertanejos, incorporados à cultura nordestina. 
O padre Ibiapina preocupado com a morte por doenças veiculadas pela água, construía uma cisterna de captação de água de chuva em cada uma das 22 Casas de Caridade. Essas Casas eram para acolher os órfãos cujos pais tinham sido vitimadas pelo cólera ou por outras doenças. O padre Cícero Romão, influenciado por Ibiapina, foi um homem atento com as populações do seu tempo. Pouco se fala da imensa generosidade do padre Cícero em acolher as pessoas que estavam sem rumo vivendo no sertão e sem terra para trabalhar. E sem água segura para beber. Em 1888, ocorreu a libertação dos escravos e muita gente não tinha pata onde ir. Muitos acabaram indo para o Juazeiro do Norte (CE). O conselheiro Ibiapina também foi uma referência religiosa para o beato Antônio, porque este é Conselheiro consagrado pelo povo e ficou destacado por conta dos seus conselhos e pregações moralizantes.

Não se trata de uma particularidade geográfica, regional, porque em outros lugares tiveram pessoas que realizaram função análoga, como Nhá Chica ${ }^{13}$ (1808-1895), em Baependi (MG) e o monge João Maria ${ }^{14}$ na região do Contestado ${ }^{15}$ (hoje, Santa Catarina). Igualmente não se pode falar de uma característica do catolicismo, pois outras tradições religiosas também têm grande afeição por guias espirituais como o guru, o pajé, o xamã e outras pessoas que fazem alguma forma de direção espiritual.

Ao referir-se ao catolicismo sertanejo este estudo tem em mente aquela forma religiosa predominante na região semiárida do Nordeste brasileiro. Pode-se questionar, mas, em que medida a figura do conselheiro está presente - ainda que sob outras denominações - em outras formas regionais de catolicismo popular brasileiro. O conhecimento acerca do conselheiro constitui um clima extraordinário de investigação das Ciências Humanas. Pois, por intermédio delas, podese fazer um estudo de cunho sociológico, antropológico, aplicar análises pertinentes à Psicologia religiosa, explorar a dimensão histórica e a geografia religiosa, à medida que se exercita o cuidado com a Língua Portuguesa.

\section{Referências bibliográficas}

ARAÚJO, Francisco Sadoc de. Padre Ibiapina: peregrino da caridade. São Paulo: Paulinas, 1996.

AZEVEDO, Thales. O catolicismo no Brasil: um campo para a pesquisa social. Brasilia: MEC, 1955.

AZZI, Riolando. História da Igreja no Brasil: ensaio de interpretação a partir do povo: tomo II/3-2: terceira época: 1930-1964. Petrópolis: Vozes, 2008. 
BARBOSA, Francisco Salatiel de Alencar. O joaseiro celeste: tempo e paisagem na devoção ao Padre Cícero. São Paulo: Attar, 2007.

BARRETO, Francisco Murilo de Sá. Padre Cícero. $2^{\circ}$ ed. São Paulo: Loyola, 2003.

BARROS, Luitgarde Oliveira Cavalcanti. A terra da mãe de Deus. Rio de Janeiro: Francisco Alves; Brasília: INL, 1988.

BOURDIEU, Pierre. Gênese e estrutura do campo religioso.A economia das trocas simbólicas. São Paulo: Perspectiva, 1974. Cap.2.

BRAGA, Antônio Mendes da Costa. Padre Cícero: sociologia de um padre, antropologia de um santo. Bauru/São Paulo: Edusc, 2008.

BRUNEAU, T. C. Catolicismo brasileiro em época de transição. Trad. de Margarida Oliva. São Paulo: Loyola, 1974.

CERTEAU, Michel de. Cultura popular e religiosidade popular. Cadernos do CEAS,Salvador, n. 40, nov.-dez. de 1975.

COMBLIN, José. Padre Ibiapina. São Paulo: Paulinas, 1993.

COSTA, Gutemberg. Profeta do Nordeste. Natal: Clima, 1994.

CRUZ, João Everton da. Frei Damião: a figura do conselheiro no catolicismo popular do Nordeste brasileiro. (Mestrado). Belo Horizonte: Pontificia Universidade Católica de Minas Gerais, 2010.

CUNHA, Euclides da. Os sertões. $23^{\circ}$ ed. Rio de Janeiro: Livraria Francisco Alves, 1954.

DELGADO, Lucília de Almeida Neves. História oral: memória, tempo, identidades. Belo Horizonte: Autêntica, 2006.

DELLA CAVA, Ralph. Milagre em Juazeiro. Rio de Janeiro: Paz e Terra, 1985.

FREYRE, Gilberto. Casa-Grande \& senzala: formação da família brasileira sob o regime da economia patriarcal. São Paulo: Círculo do Livro, 2006.

HALBWACHS, Maurice. A memória coletiva. São Paulo: Centauro, 2004.

HERVIEU-LÉGER, Daniele. O peregrino e o convertido: a religião em movimento. Trad. de João Batista Kreuch. Petrópolis: Vozes, 2008.

HOLANDA, Sérgio Buarque de. Raízes do Brasil. 26º ed. São Paulo: Companhia das Letras, 1995.

HOORNAERT, Eduardo. A distinção entre "Lei" e "Religião" no Nordeste. Revista Eclesiástica Brasileira. Petrópolis: Vozes, v. 29, n. 3, set. de 1969. p. 580-606.

HOORNAERT, Eduardo. Formação do catolicismo brasileiro: 1550-1800. $3^{\circ} \mathrm{ed}$. Petrópolis: Vozes, 1991.

LÉVI-STRAUSS, Claude.Antropologia estrutural. Rio de Janeiro: Tempo Brasileiro, 1975.

LIMA, Antônio Carlos Ferreira. Permanência do ciclo místico-religioso na literatura de cordel e sua correção com os niveis de construção textual. Tese (Doutorado). 
Maceió: Universidade Federal de Alagoas, 2008.

LOPES, Diana Rodrigues. Padre-Mestre Ibiapina e Casa de Caridade de Triumpho - PE. Santa Cruz da Baixa: Gráfica Folha do Interior, 2004.

MENEZES, Eduardo Diatahy B. de. Pe. Ibiapina: figura matricial do catolicismo rústico do Nordeste do século XIX.Encontro Anual daANPOCS, 20, 1996. Caxambu. Anais... Caxambu, 1996.

NETO, Lira. Padre Cícero: poder, fé e guerra no sertão. São Paulo: Companhia das Letras, 2009.

NUVENS, Plácido Cidade. Tentativas de Caracterização da Romaria de Juazeiro do Norte. Seminário de 150 anos de Padre Cícero, 1994, Fortaleza/Juazeiro do Norte. Anais...Fortaleza/ Juazeiro do Norte: Editora RCV, 1994, p.25-30.

OLIVEIRA, Pedro de Assis Ribeiro de. Adeus à sociologia da religião. Religião e Sociedade. Rio de Janeiro: ISER, v. 18, n.2, 1997. p. 43-62.

OLIVEIRA, Pedro de Assis Ribeiro de. Catolicismo Popular e romanização do catolicismo brasileiro. Revista Eclesiástica Brasileira. Petrópolis: Vozes, n. 14, março de 1976. p. 131-143.

OLIVEIRA, Pedro de Assis Ribeiro de. Religião e dominação de classe: gênese, estrutura e função do catolicismo romanizado no Brasil. Petrópolis: Vozes, 1985.

OLIVEIRA, Pedro de Assis Ribeiro de. Religião e dominação de classe: o caso da "Romanização". Centro de Estatísticas Religiosas e Investigações Sociais. Rio de Janeiro: CERIS, 1980.

OLIVEIRA, Pedro de Assis Ribeiro de. Religiosidade popular na América Latina. Revista Eclesiástica Brasileira. Petrópolis: Vozes, v. 32, n.126, junho de 1972. p. 354-364.

ROLIM, Francisco. Condicionamentos sociais do catolicismo popular. Revista Eclesiástica Brasileira. Petrópolis: Vozes, v. 36, n. 141, março de 1976. p. 142170.

SANTANA, Manoel Henrique de Melo. Padre Cícero do Juazeiro: condenação e exclusão eclesial à reabilitação histórica. Maceió: EDUFAL, 2009.

SILVEIRA, Ildefonso. Estado atual da pesquisa sobre Padre Cícero. Revista Eclesiástica Brasileira. Petrópolis: Vozes, v. 36, n. 141, março de 1976. p. 226-260.

SOBREIRA, Padre Azarias. O patriarca de Juazeiro. Petrópolis: Vozes, 1969.

STEIL, Carlos Alberto. O sertão das romarias: um estudo antropológico sobre o santuário de Bom Jesus da Lapa. Petrópolis: Vozes, 1996.

TEIXEIRA, F. Faces do catolicismo brasileiro contemporâneo.TEIXEIRA, Faustino; MENEZES, Renata (org.). Catolicismo plural: dinâmicas contemporâneas. Petrópolis: Vozes, 2009. Cap. 2. p. 17-30. 
${ }_{1}$ Nasce, no dia 05 de agosto de 1806, o futuro padre Ibiapina, cearense, nascido na fazenda Morro da Jaibara, Sobral (CE). Padre secular desde 1853, foi ordenado por dom João da Purificação, com 47 anos de idade.

2 Nasce, no dia 13 de março de 1830, em Vila do Campo Maior de Quixeramobim (CE), o futuro Antônio Conselheiro, filho de Vicente Mendes Maciel e Maria Joaquina do Nascimento - de alcunha Maria Chana.

3 Nasceu no Crato (CE), no dia 24 de março de 1844, o futuro "Padrinho Cícero ou "Padim Ciço", carinhosamente chamado, precisamente na Rua Grande, hoje rua Miguel Limaverde. Filho de Joaquim Romão Batista e Joaquina Vicência Romana, a Sinhá Quinô”.

4 Foi batizado com o nome de Pio Giannotti, o futuro frei Damião, capuchinho, nascido no dia 05 de novembro de 1897 em Bozzano (Lucca), Itália, filho de Félix e Maria. Foi ordenado sacerdote em Roma, em 05 de agosto de 1923. Em 29 de setembro de 1931, ano que chegou ao Brasil, celebrou a sua primeira missão no Brasil, na Capela de São Miguel, em Gravatá (PE). Quando dom Vicente de Matos, em 1970 e em 1975, pediu a frei Damião que não pregasse mais santa missão no Crato (CE), o povo comentava: Estão proibindo frei Damião, como proibiram padre Cícero. Querem é acabar com a religião.

5 José Calasans (Silva, 1986) diz que na igreja popular sertaneja, há uma hierarquia; de beato passa a ser conselheiro. O beato podia ter uma progressão, quando ele "adquiria condições para, além disso, proferir prédicas, ou conselhos, passava a conselheiros” (Galvão, 2001, p. 33).

${ }^{6}$ No dia 17 de julho de 2008 entrevistei a Fundadora do Movimento Grupo Jesus Vive, na cidade de Nossa Senhora das Dores (SE), médio sertão, em sua residência, a professora aposentada, D. Maria Iolanda Araújo de Andrade, na época, 69 anos de idade, ela declarou-me que o "Grupo Jesus Vive nasceu a partir do Natal em família, no dia 7 de janeiro de 1985 e que se reunia semanalmente para visitar os doentes, ler a Bíblia e fazer uma Via-Sacra na Semana Santa, (procissão) rezando para chover - saindo da Igreja Matriz de Nossa Senhora das Dores (às quatro horas da manhã) com destino ao Cruzeiro do Século, na saída da cidade em direção a Serra do Machado, situado acerca de $5 \mathrm{Km}$ do centro da cidade. A manifestação teve continuidade e hoje reúne, anualmente, na sextafeira da Semana Santa, centenas de devotos em peregrinação e penitência. Atualmente a Procissão do "Cruzeiro do Século" é um espaço de devoção e Patrimônio Cultural e Imaterial do Estado de Sergipe. (Lei No 8.051 de 22 de outubro de 2015).

7 Desde a antiguidade cristã, a Confissão é chamada de "segunda tábua [de salvação] após o naufrágio da graça perdida", assim como um "segundo Batismo", ou "uma espécie de Batismo que exige compromisso" (laboriosus quidam Baptismus), conforme cita o Concílio de Trento. (GIRAUDO, Cesare. Confessar os pecados e confessar o Senhor. São Paulo: Edições Loyola, 2015, p. 7).

$8 \mathrm{Na}$ elaboração desta resumida biografia foram consultados os seguintes autores: Comblin (1993), Araújo (1996), Menezes (1996) e Lopes (2004), cujas obras constam nas referências.

$9 \mathrm{Na}$ construção desta pequena biografia consultamos os seguintes autores: Fiorim (1980), Hoornaert (1997), Benício (1997), Silva (1986 e 1997) e Galvão (2001), cujas obras estão citadas nas referências.

10 Para elaboração desta biografia foram consultados os autores: SOBREIRA (1969), Della Cava (1985), Nuvens (1994), Barreto (2003), Barbosa (2007), Braga (2008), Santana (2009), Neto (2009), Poel (2013) e Dumoulin (2017), cujas obras estão citadas nas referências.

11 Para elaboração desta breve biografia baseamo-nos: Moura (1978), Silva (1991), Oliveira (1997), Maior (1998) e Torres (2004), cujas obras estão citadas nas referências.

12 A "Carta Aberta ao Frei Damião - Grande Homem de Fé" foi escrita pelo advogado Costa Pereira, da Liga Camponesa de Pesqueira, Pernambuco, no dia 5 de novembro de 1960 e publicada no jornal "O Semanário", Rio de Janeiro.

13 Francisca de Paula de Jesus, era mestiça, filha de escrava e analfabeta, nasceu no distrito de Santo Antônio do Rio das Mortes, em São João del Rei (MG), em 1808, mas mudou para Baependi (MG) ainda criança. Com 10 anos de idade, ficou órfã da mãe. Ela nunca se casou. Atendia a todos os que procuravam e tinha sempre uma palavra de conforto, um conselho ou uma promessa de oração. Sabia dialogar, mostrando-se sábia e serena. Nhá Chica morreu no dia 14 de junho de 1895, com 87 anos de idade. Os restos mortais dela se encontram no interior do Santuário Nossa Senhora da Conceição, em Baependi. Seu processo de beatificação iniciou-se em 1993. Complementou-se em 1998. A sua causa foi assumida pela Congregação das Causas dos Santos, em 2000. 
O Papa Bento XVI, em janeiro de 2011, reconheceu a prática das virtudes cristãs, vivenciadas pela Venerável Nhá Chica. (Passarelli, 2013, p. 9-13).

14 Vale a pena informar que houve pelo menos três monges João Maria, vivendo em épocas distintas. Um cujo aparecimento remonta à década de 1850. Outro com presença marcante entre os sertanejos, aparecido na década de 1890. O terceiro aparecido na década de 1910 (Marli, 2015, p. 53).

$15 \mathrm{O}$ termo Contestado indica a região de $48.000 \mathrm{Km}^{2}$ entre a fronteira da Argentina e os rios Uruguai e Iguaçu do Peixe que foi disputada, há um século, pelos estados do Paraná e Santa Catarina. Houve conflitos armados.

Recebido em 05/07/2021 Aceito para publicação em 06/09/2021 